\title{
"Ega ma arsti juurde ju ometi ei lähe!" Eemiline uskmatus oletataval uue vaimsuse uurimisväljal
}

\author{
Age Kristel Kartau \\ Tartu Ülikooli usuteaduskonna doktorant \\ age.kartau@gmail.com
}

\begin{abstract}
Teesid: Käesolev artikkel vaatleb vastuolu rahvusvahelise religioonisotsioloogia paradigmas kogu alternatiivmeditsiini uueks vaimsuseks pidamise ja Eestis selles vallas tegutsejate mitte-religioosse enesenägemuse vahel. Tai massaaži, jooga ja loodusravide pakkujad ei loe oma töö tulemuslikkust usul põhinevaks platseeboefektiks, vaid selgitavad seda eelkõige asjalikest ja materialistlikest asjaoludest lähtuvalt. Põhjuslikku seost võib näha inimloomusele omases uudishimus sakraalsuse suhtes koos keeldumisega olla alandlik ajaloolise vägivallakogemuse, kultuuritrauma najal hüpertrofeerunud enesesäilitustungi tõttu.
\end{abstract}

Märksõnad: kehatehnikad, manuaalmeditsiin, materialism, new age, religioonisotsioloogia, usk, uskmatus

\section{Sissejuhatus}

Riigimeditsiin, alternatiivmeditsiin, komplementaarmeditsiin; riigiharidus, eraharidus, alternatiivharidus; tippsport, rahvasport, ravikehakultuur, alternatiivsed kehatehnikad - selliste mõistekobarate loomise võimalus peavoolu ja alternatiivi vastandamise kaudu erinevates eluvaldkondades annab märku kaasatud inimeste maailmavaatelistest erinevustest. Poola religioonisotsioloog Bronislaw Szerzynski (2005: 15) peab kogetava reaalsuse üheks tahuks sakraalsust, mis taasilmub ka kirikut eitavale inimesele, tänapäeval näiteks inimkeha, looduse ja tehnikaga seotud sotsiaalsetes praktikates difuusse spirituaalsusena, mida ta ise nimetab piltlikult "kultuurimaastikul ringi hulkuvaks metsikuks religiooniks" (feral religion roaming around abroad cultural landscape). See idee võib aidata kirjeldada eesti rahva üldist religioonitõrksust ning ebaselges sõnastuses väljendatavat poolehoidu "millelegi muule". Rahvusvaheliste sotsioloogiliste küsitluste tulemuste järgi kuulub Eesti maailma kõige sekulariseerunumate riikide hulka ja pooldab new age'i uurimisküsimuste sõnastusi. New age'i autoriteet Paul Heelas (2013: 167) märkis 2010 küsitlusvastuste tõlke juures silmapaistvana ära selget seisukohavõttu vältiva "pigemlikkuse" (ratherism): peaaegu igale "küsimusele, kas te usute...?" eelistavad eestlased 
vastata mitte "jah" ega "ei", vaid "pigem jah" või "pigem ei". Atko Remmel ja Marko Uibu (2015) kirjeldasid seda Eestis valdavat mitte-religioossust kui eelkõige ükskõiksust ja isegi religioosset kirjaoskamatust normina tajutava kristluse osas. Käesolevas artiklis püüan näha selle religioonitõrksuse põhjuslikku seost Laur Lilleoja, Indrek Tarti, Marko Sõmeri, Maris Raudsepa jt sotsioloogide alusväärtuste küsitlusega, mille järgi eestlaste silmis on kahekümne ühe väärtuse seas kõrgel kolmandal kohal isikuvabadus, soov ise otsustada, olla vaba ja teistest sõltumatu (Lilleoja \& Raudsepp 2016) - ehk nähtus, mida kristlik praktiline teoloogia mõistab hukka alandlikkuse vastandina ning nimetab autarkiaks (ingl self-sufficiency), enese (aut-) [iseseisvalt] valitsemiseks (-archia) ilma Jumala poole pöördumiseta.

Artikli alguses kirjeldan oma kvalitatiivset uuringut Tai massaaži maaletoojate elulugudest aastail 2008-2011 ning enda kui uurija teekonda ajaloolase paradigmast kultuuriteooria ja sotsioloogia töörühma ning sealt edasi religiooniuuringute ja teoloogia radadele koos mitmete kontseptuaalsete ja terminoloogiliste raskustega, mis kaasnevad siirdumisega ühe distsipliini mõistestikust teise. Seejärel keskendun nn uue vaimsuse ala kirjeldamisele, mis jääb monoteismi ja religioossuse vastasuse vahele, kasutades religioonisotsioloogia meetodeid. Edasi refereerin uskumist uurivaid küsitlusi ja tõlgendusi tänase Eesti olukorrast, eriti nn uue vaimsuse kohta, pakun oma empiirilisest materjalist eemilisi hinnanguid, mis astuvad dialoogi religioonisotsioloogilise numbrilise andmestikuga, seda kas kinnitades või sellega vastuollu minnes, vaatlen lähemalt Karl Jaspersi transtsendentaalse telje purunemise ideed Szerzynski "hulkuva religiooni" käsitluses ning enne artikli lõppu otsin intervjuudest Eesti inimeste mõningaid mõtteid selle teooria ilmestamiseks.

\section{Empiiriline uuring}

Käesolev artikkel toetub kolmekümne neljale eluloointervjuule, mis on lindistatud aastatel 2008-2011 ja on hoiul Eesti Kirjandusmuuseumi Eesti Rahvaluule Arhiivi (ERA) digitaalses heliarhiivis (DH 287-311 ja 398-405), kasutatud on ka mõnda hilisemat suulist arvamuseavaldust eravestluste käigus.

Neist intervjuudest üksteist oli kasutusel magistritöös "Traditsioonilise Tai massaaži nuad bo rarn Eestisse jõudmine elulugude andmetel" (Kartau 2011a). Valim moodustus lumepallimeetodil ja intervjuud olid oma ülesehituselt struktureerimata eluloointervjuud kestusega ühest nelja tunnini. Vastavalt kokkuleppele intervjueeritavatega on vastused kodeeritud ja 25aastase ligipääsupiiranguga. 
2008. aastal Tai massaažiga seotud elulugude lindistamist alustades nägin end lähiajaloolasena. Tartu Ülikooli ajalooteaduskonna kasvandikuna alustasin tahes-tahtmata Georg Friedrich Ranke positivistliku kreedoga "Kuidas see tegelikult oli?" (Wie ist es eigentlich gewesen?) - millised sündmused nende elus ajendasid vastajaid õppima massaaži kui käelist raviviisi (ehk manuaalmeditsiini), miks hakkas keegi neist huvi tundma idamaiste oskuste vastu ja kuidas eestlastele meeldib või toob kasu aastatuhandete pikkuse kogemusega ravikunst Taist.

Ainestiku anonüümseks kodeerimise ja teadusliku kirjanduse otsimise käigus selgus, et mu materjal pakub huvi religioonisotsioloogiale, kus alternatiivmeditsiin ehk komplementaarmeditsiin ehk täiendmeditsiin tervikuna loetakse new age'i ehk uue vaimsuse osaks. Colin Campbell on uue vaimsuse jaoks välja pakkunud mõiste "kultusmiljöö" (vt allpool), mis olemuslikult koosnebki hereesiast, ketserlusest, vastukultuurilisusest ja toimib uute ideede taimelavana. Ka sõna "alternatiiv" tähendab üha uuemate võimaluste otsimist. Seega on arusaadav, et alternatiivmeditsiinis ühte peavoolu ei ole ega tulegi. Tai massaaž on olnud Eestis juba ligi 20 aastat üks koolides ja täiendkursustel õpetatav tehnika. Kehatehnikatest kõige levinum on Eestis tõenäoliselt jooga (eriti, kui selle erinevatele vooludele lisada jooga ja ravivõimlemise alusel loodud Pilatese treeningud). Indiast Chennaist pärit krishnamacharya jooga guru Khaustub Desikatchar on ühele eestlannale väljendanud imetlust, et võrreldes rahvaarvuga (sest Indias on üks miljon elanikku piir küla ja linna vahel) tehakse Eestis joogat palju rohkem kui Indias (n 1956, ERA DH 306).

Kehatehnika mõiste tõi kasutusele sotsioloogia klassik Marcel Mauss (1934), nimetades nii kõike kultuuri kaudu kehaliselt omandatavat - rühist ja kõnnakust söömise, tantsimise ja sünnitamiseni. Märkimist väärib, et suure hulga eluloointervjuude üldistusena võib öelda, et enamik orientaalseid kehatehnikaid on Eestisse toodud Läänest - Hiina nõelravi Hispaaniast, jooga Soomest, Rootsist, Austriast ja Prantsusmaalt, Tai massaaž Rootsist (Kartau 2011a). Ehkki ma ise ega mu küsitletud ei tunne end orientaalsete kehatehnikate oskamise kaudu religioosseks määratledes mugavalt, andis religioonisotsioloogia väide new age’i ja täiendmeditsiini seosest mu töös kogutud empiirilisele materjalile mind ennast üllatava metodoloogilise raamistuse ja kaalukuse. Oma arutelus, mida kõike inimese keha võib ära õppida, kirjutas Mauss (1934: 22-23) juba 85 aastat tagasi: "Usun, et inimmeele kõigi müstiliste elamuste taustaks on kehatehnikad, mida ei ole küll uuritud, ent mida täielikult õpiti Hiinas ja Indias väga iidsetest aegadest peale. See sotsio-psühho-bioloogiline uurimistöö müstilisuse kohta tuleb ära teha. Kindlasti on olemas hädavajalikud bioloogilised viisid selleks, et astuda "suhtlusse Jumalaga"." 


\section{Religiooni määratlused}

Religiooniuuringute valdkonnas kirjutamine eeldab oma valiku tutvustamist ka selle ala arvukatest erinevatest definitsioonidest. Antropoloog Clifford Geertzi (1990: 2303) definitsiooni kohaselt on religioon "sümbolite süsteem, mis võimaldab tekitada inimestes tugevaid, täielikult haaravaid ja kauakestvaid meeleolusid ja motivatsioone, formuleerides arusaamu eksistentsi üldise korralduse kohta ja ümbritsedes need arusaamad säärase tegelikkuse auraga, et need meeleolud ja motivatsioonid näivad ainulaadselt elulähedased”.

Religioonifilosoof Jan-Olav Henriksen defineerib religiooni kui "sümbolites vahendatud kogemust eraldi asetatud asjadest", viidates "eraldi asetatud asjadena" Ann Tavesi ideele pühadusest kui "asjadest, mida me oleme otsustanud tajuda religioossena" (Henriksen 2017: 104). Mõiste püha kui "argisest erineva, salapärase tõelisuse, millega inimene võib kohtuda ja millega kohtumist ta elab üle sügavalt emotsionaalselt", tõi religioonifilosoofiasse juba Nobeli preemia laureaat, Rootsi peapiiskop Nathan Söderblom (1914). Ka religiooniloolane Rudolf Otto seadis 1917. aastal religiooni keskmesse mõiste püha, numinoosse, võõrastava, hirmuäratava ja ligitõmbava (Otto 2003, 2012). Henrikseni maksimalistliku teooria järgi on elav usk "orienteerumise, transformatsiooni ja legitimatsiooni” vahend, mida metafoorselt saab vaadelda näiteks koduna või orkestri partituurina (Henriksen 2017).

Religiooni interdistsiplinaarsetele uuringutele keskenduv Robert Yelle peab ajaloolisi religioone üheks inimühiskonna kommunikatsiooniviisiks, "kultuuride retoorikaks" ning lähtuvalt Michel Foucault' diskursiivsete formatsioonide mõistest isegi millelegi kellegi jaoks tähenduse omistamist ja tõlgendamist reguleerivateks "semiootilisteks ideoloogiateks" (Yelle 2016). Veelgi põnevama seisukoha esitab religioonisemiootik Massimo Leone, kelle väitel nii ajaloolised religioonid kui ka kõik muud uskumuste süsteemid (kommunism, natsionaalsotsialism, meesšovinism, feminism) on teadvuse turvavõrgustik, "kaasasündinud lõpmatustunde grammatika maatriks", mis aitab piirata tulevaste käikude planeerimiseks vajalike "potentsiaalsuste sümboolsete simulaakrumite" hulka ajus, mis ilma mingi limiteeriva reeglistikuta mõjuksid närvisüsteemile paralüseerivalt (Leone 2012).

Käesolevas artiklis kasutan sõna "religioon/religioosne" üldtunnustatud ajalooliste religioonide üldnimetusena, väljendeid "new age" ja "uus vaimsus" eelnevalt viidatud tähenduses teoorias või statistilises küsitluses selleks nimetatava nähtuse üldistava sildina. 


\section{Budismi ravimeetod}

Meditsiinisüsteemis kuulub massaaž füsioteraapiliste ravimeetodite alla, kuid enamik inimesi võib tänapäeval massaažiga kokku puutuda eelkõige salongiteenusena. Kahjuks kasutatakse massaaži nimetust väga sageli ka inimkaubanduse ja prostitutsiooni eufemismina. Professionaalse massööri töös ega enesemääratluses sellist seost kindlasti ei esine.

Eesti geograafilise asukoha tõttu on käibel jaotus ida ja lääne massaažid. Lääne massaažid vastavad meditsiinisüsteemi ootustele, stereotüüpselt tehakse neid lahti riietudes ja massaažilaual, tihtipeale ka õliga, kuid see pole obligatoorne. Ida massaažid kuuluvad oma ülesehituselt kokku rohkem füsioteraapia ja ravivõimlemisega, üldjuhul tehakse neid läbi riiete ja põrandal spordimatil, mis võimaldab massööril töötada palju ergonoomilisemalt, rohkem oma keharaskust ja gravitatsioonijõudu kasutades, mistõttu protseduuri füsioloogiline tulemuslikkus on oluliselt parem.

Tai massaaž kuulub ida massaažide hulka ja pärineb religioossest õpetusest - ta on osa 2500 aastat vanast theravāda budismist (= Sri Lanka, Myanmari ja Tai hinayāna budism vastandina Tiibeti, Hiina ja Jaapani mahāyāna budismile). See määratleb üheselt ka algse ülesandepüstituse: teha füsioloogilise lihasvenivuse parandamisega võimalikuks pika valgustumismõtluse jaoks vajalik lootosiste kehaasend.

Tai massaaž on iseenesest väga kehaline nähtus ja kuigi ravitsejale vähemalt Taimaal on budistlikud palved töö alustamiseks ette nähtud, ei tehta massaaži käigus mingisugust religioosset selgitustööd kliendile. Euroopas Tai massaaži pakkuvad massöörid enamasti isegi ei oska wai khru'd (austusavaldus õpetajale) peast lugeda, rääkimata selle meloodiaga retsiteerimisest. Siiski pannakse ka euroopalikesse Tai massaaži õpikutesse sisse käsk panna enne kliendi kehale käte asetamist oma pihud rinna ees kokku ja teha mõned sügavad hingetõmbed enese meditatiivseks keskendamiseks kliendi heaolule.

Budismi raames väidetakse, et Tai massaaž on üks viis neljast võimalikust "jumalikust meeleseisundist" ühe - metta ehk armastava lahkuse (ingl loving kindness ) - üleandmiseks ühelt inimeselt teisele (Kartau 2011b).

Kõige kuulsama rahvusvahelise kirjelduse budistliku Taimaa ravikunstist esitas juba 1691. aastal päikesekuningas Louis XIV-le laevareisilt naasnud Prantsuse kuninga erakorraline ja täievoliline suursaadik Siiami kuninga õukonnas Simon de la Loubère: "Kui Siiamis mõni inimene haigeks jääb, siis alustab ta sellest, et lasta oma keha pehmendada kellelgi, kes on selles osav, kes tõuseb haige keha peale püsti ja trambib teda jalge alla" (de la Loubère 1691: 192). Raamat "Description du royaume de Siam", milles see lause on kirjas, oli kirjutatud aastatel 1687-1688 toimunud diplomaatilisi sidemeid rajava 
laevareisi muljete põhjal. See raamat tõi autorile koha Prantsuse Teaduste Akadeemias.

Tänane Tai massaaž on olnud budistlike kloostrite manuaalmeditsiin juba enne seda, kui praeguse tai rahvuse eelkäijad umbes aastal $1000 \mathrm{pKr}$ oma praegusele asualale liikusid, juba siis, kui seda piirkonda asustasid alles moni rahvusest inimesed, kelleni budism levist Indiast Ašoka impeeriumi ajal. Taikeelne nuad bo rarn tähendab "vana raviviisi" ning selle alglegend on seotud budismi alglegendiga ${ }^{1}$ ja seetõttu ka Põhja-India Bihari osariigi Rajiri linna ümbrusega, mitte Taimaaga. Ka Tiibetisse ja Hiinasse levinud mahāyāna budismi manuaalmeditsiini võtted ja põhiskeemid on sellega äratuntavalt sarnased. Euroopasse ja USAsse 1990. aastate alguses levinud Tai massaaži teenus salongimassaažina sai kõnekeelse nimetuse "laisa inimese jooga", sest täisriietuses tehtav protseduur sisaldab lisaks mitmesugustele gravitatsioonijõu kasutamise abil väga ergonoomilistele lihasvajutustele ka palju erinevaid visuaalselt üllatavaid venitusasendeid, kus massööri ülesanne on klient passiivselt "läbi võimelda" (Kartau 2011a, 2011b, 2012).

\section{Teekond Eestisse}

Tai massaaž jõudis Eestisse päikeseturismi vahendusel. Skandinaavia lennufirma SAS ühele eestlasest töötajale pakuti 2000. aastal perepuhkuseks tasuta lennupileteid Taisse Koh Samui saarele. Töötaja naine (A) oli elukutseline tantsija ja tantsuõpetaja, kes oli just aasta varem läbi elanud suure kriisi, mille järel tal oli hirm, kas ta üldse elus enam tantsida saabki. Enne reisile minekut oli ta hakanud õppima joogaõpetajaks ja juhendas mõnda joogatreeningut. Ehkki talle oli öeldud, et Tai massaaž on väga hea, ei leidnud ta enne perepuhkuse lõppu kordagi võimalust seda kliendina kogeda, ostis aga koju kaasa raamatuid ning uuris neid omal käel. Tagasi oma joogarühma jõudes lülitas ta autodidaktina raamatust õpitud passiivsed liigutused sujuvalt oma joogatundidesse (n 1965, ERA DH 307). Üks tema joogatreeninguil osaleja (B) kirjutas sellest Eestis veel tundmatust kehatehnikast artikli (n 1962, ERA DH 290).

Eestile eripärane võis olla intensiivne vajadus sellise massaaži järele, tühi nišš, mis oli 2001. aastaks tekitatud bürokraatlike meetmetega. Maaletoojate ahela kolmas lüli (C), kes sõitis ajakirjast loetud artikli tõukel Rootsi Axelsoni võimlemisinstituuti (Axelsons Gymnastica Institutet) Rootsi abiellunud tailanna Tai massaaži kursusele, lootis 2001. aasta kevad-suvel, et alates septembrist kuulub talle Eesti kõige esimene erakutsekool (m 1954, ERA DH 288). Ta oli nõukogude ajal õppinud kehalise kasvatuse õpetajaks ning tutvuste kaudu pääsenud õppima ka massööriks. Alates 1996. aastast teenis ta raha nõukogude 
perioodil defitsiidiks muudetud massaažioskuse edasiõpetamisega. Senised kursused olid nelja aasta jooksul koosnenud enamasti 40 õppetunnist. 2001. aasta kevadel koostati Euroopa Spordimassööride Assotsiatsiooni veebilehel haridusnõuete kohaselt 1000 tunni pikkune massaažikooli õppekava. Tegijatele endile tundus see väga suure saavutusena. Litsentsi saamiseks Riiklikku Eksami ja Kutsekvalifikatsiooni Keskusesse pöördumisel varisesid kõik lootused põrmu: taotlejale teatati, et Eesti Vabariigi kutsehariduse standard näeb ette kutsekooli õppekava mahuks mitte vähem kui 1600 tundi. Nii oli esmalt vaja minna Rootsi Tai massaaži õppima, et täita riiklikke nõudmisi avatava kooli õppekava mahu osas. (m 1954, ERA DH 288)

Siis, kui Tai massaaži õppetöö Rootsi kaudu Eestisse jõudis, vaadeldi seda vaid ühe füsioteraapilise tehnikana. Tai massaaži tänane tähendus Eestis on peamiselt sekulaarne ja äriline - väga paljudele selle kehatehnika oskajatele on see lihtsalt üks tehniline oskus mitmete teiste samalaadsete seas. Kui 2005. aastal koostati Riiklikus Eksami-ja Kutsekvalifikatsiooni Keskuses riiklikku massööride kutsestandardit, õpetati massaaži Eestis ametlikult kuues koolis ning neist mitmekesiseim õppekava sisaldas 13 massaažiliiki. Pärast 2008. aasta majanduskriisi on suurte koolide arv kahanenud, kuid väikeste koolitusettevõtete hulk kasvanud astmeliselt ning seoses turu nõudmistega on toodud sisse veel pea loendamatus koguses uusi teemasid.

See, et theravaada-budistlik Tai massaaž kui algselt nirvaana-teekonda kuulunud religioosne kehatehnika täidab Eestis sekulaarset, ärilist ja meditsiinilist rolli, on usutavalt sarnane ka kogu ülejäänud Euroopa olukorraga. Teatud määral alustati sekulariseerimist kindlasti juba Taimaal. 2004. aastal Saaremaal Georg Ots Spa avamisega sai Tai massaažist Eesti spaade konkurentsivõitluses üks rahalise kasu teenimise vahend (ERA DH 302).

Märgatavalt erinevad koolkonnad Eesti Tai massaaži õpetajate seas tekkisid siis, kui budismiteadlik joogataustaga inimene, kes oli Tai massaaži meediakajastuste käivitaja (B), sisenes uuesti õpilasena tema enese teksti põhjal kujunenud õppetöö kogukonda. Ta leidis, et Rootsist idamaise kehatehnika importimine on taunimisväärne ja ajendas oma vahetut õpetajat (D) sõitma 2005. aastal Taisse ennast täiendama (m 1968, ERA DH 290). Et konkurendid hilinesid sellega vähemalt kolm aastat (esimene grupp 2008), kujunes võistlevate koolide õpetamisstiil oluliselt erinevaks.

Tai Kuningriik läänestus 20. sajandi jooksul üsna märkimisväärselt - tulevane kuningas käis Euroopas, edu saatis lääne meditsiini sissetoomist ja läänelike turundusstrateegiate omandamist. Tai massaaž isegi keelati riigis ajutiselt 20. sajandi alguspoolel. Alates 1962. aastast aga õpetati seda Vana Meditsiini Haiglas (Old Medicine Hospital) Chiang Mais ja Wat Po kloostri meditsiinikoolis Bangkokis. Mujal maailmas ei teatud sellest 1980. aastate 
lõpuni peaaegu mitte midagi, kuni 1990. aastal tõi sakslane Harald Brust ehk Asokananda turule oma raamatu Tai massaažist. Seepeale spondeeris äriliselt taiplik Taimaa valitsus kiiresti 800tunnist programmi tai rahvusest õpilastele Tai traditsiooniliste ravikunstide õpetamise elavdamiseks ning 18 õpetajat leppisid 1991. aastal omavahelisel nõupidamisel Wat Pos kokku ühtse algõpetuse programmi. Nii loodi seni õpetajalt õpilasele individuaalselt ja suuliselt edasi õpetatud variatsiooniderikkast pärimuslikust kehatehnikast riiklikult ühtlustatud, selgete juhistega ja ka turistidele suunatud õppeprogramm. Seega tõid eestlased Tai massaaži algkodust erinevate erakutsekoolide omavahelises konkurentsivõitluses kaasa üsna läänestatud idamaise oskuse (ERA DH 290, 292, 288, 293, 294, 302-2). Tänaseks õpetatakse Eestis ka Tai massaaži mitmes koolis erinevat moodi - näiteks eraldi Wat Po templikoolis õpetatavat ning Chiang Mai Rahvusvahelise Tai massaaži kooli (International School of Thai Massage) varianti - ning lisaks nn Tai jooga-massaažile pakutakse ka Tai jalamassaaži, Tai õlimassaaži, Tai ravimtaimede soojakottidega massaaži ning võimalik, et veel millegi kursusi.

Kuivõrd Hiina nõelravi teooriale tuginev Hiina punktmassaaž on probleemispetsiifiline ega võimalda õpetada ühte terviklikku massaažiprotseduuri käiku, on Tai massaaž vähehaaval järjekindlalt tõrjunud massaažikoolidest kõrvale Hiina punktmassaaži kui ida massaaži põhikuvandi. Seetõttu pole Tai massaaži oskavate inimeste arv Eestis sugugi väike. Enne 2008. aasta majanduslangust oli Eesti kutseharidusturul vähemalt kuus konkureerivat massaažikooli, millest vähemalt kolm õpetasid ka Tai massaaži, neist üks nii eesti- kui ka venekeelsetele õpperühmadele. 2005. ja 2006. aastal välja töötatud ja kinnitatud massööride riikliku õppekava ja kutsestandardi järgi on Tai massaaž n-ö peamise ja juhtiva ida massaažina massööride kohustuslikus õppeprogrammis ja seda puudutavad küsimused on lülitatud ka massööride kutseeksamisse. Kutseeksam ei ole seni olnud massöörina tööle saamiseks kohustuslik ning kõik varem õppinud massöörid töötavad arvatavasti ilma kutsetunnistuseta.

Tõenäoliselt on Eestile eripärane paljude muude valdkondade inimeste huvi massaaži õppimise vastu: enamik Eestis massaaži õppinud inimestest ei lähe ametlikult massöörina tööle. Tele2 klienditeenindaja, IT-firma mänedžer, konservitööstuse turundusjuht, rätsep, kokk, ehitaja, ajakirjanik ja paljude teiste erialade esindajad peavad mõttekaks kulutada üsna suuri summasid manuaalmeditsiini oskuste omandamiseks, ning paljud neist ei teeni kunagi selle elukutsega seda raha tagasi. 


\section{Uus vaimsus ja kultusmiljöö}

Euroopalik religioonisotsioloogia on kristluse-keskne, teadusena sõnastatud vastavalt kristliku kultuuriruumi paradigmadele. Tuginedes Michel Foucault diskursuse välistamisviisidele, selgitab Wouter J. Hanegraaf (2005: 228), et esoteerika (maagia, okultismi, ketserluse jmt) mõiste alla on koondatud kõik kehtestatud ideoloogia seisukohalt problemaatilised nähtused, mida enam ei loeta nii ohtlikuks, et neid ära keelata, kuid mida naeruvääristatakse kui irratsionaalseid või valesid.

Maailma üks juhtivaid new age’i teoreetikuid Paul Heelas, kelle 1996. aasta raamat pani aluse new age'i määratlemisele eraldi ideoloogiliselt sidusa religioosse liikumisena, kirjutas EUU 2010 küsitluse tulemuste tõlke alusel terve artikli Eestist kui suurepärasest näitest "kristluse korratust taganemisest" (shattering retreat of Christendom) Charles Taylori termini kohaselt (Taylor 2007: 514; Heelas 2013: 167).

21. sajandi alguse inimene leiab pühadust üha enam oma kogemustest, aga mitte kiriklikult määratletud kogemisviisidest, ning füüsiline meetod ja viis, kuidas püha kogetakse, on tugevalt muutunud, väidab oma globaalkristluse ajaloos ka Riho Saard (2013: 583). Varem kogeti pühalikkust kirikus seistes või istudes ja jutlust kuulates, nüüd püüab inimene pühaga kokku saada rohkem oma keha liikumisele, kõndimisele, hingamisele ja venitusharjutustele tähelepanu pöörates. Näiteks Helsingi Agricola kirikus viiakse juba pikemat aega läbi kristlikke Jeesus-jooga kursusi. Kuigi kirik on andnud oma kollektiivsele suhtlemisvormile igavese õndsusega seotud tõotusi, on tänapäeva haritud inimene teadvustanud, et koguduslik suhtlemisvorm on ainult üks vorm paljude teiste pühaga seotud suhtlemisvormide kõrval ning kogudusel ei ole pühaga suhestumisel mingeid absoluutsuse eeliseid (Saard 2013: 583). Kuna selline arengutendents nõuab üldist muutust kogu maailma religiooniuuringute distsipliinis, on Heelase arvamuse kohaselt Eesti new age'i vaimsuse ja religioossuse uute arengusuundade uurimise ideaalne katselabor (Heelas 2013: 167).

Samas on new age'i silt muutunud ülilaialt kasutatavaks: see kehtib automaatselt mitmesuguste võtmesõnade - nagu "energia", "otsija", "teel olemine", "sisemine areng", "kasvamine", "teadvus" jmt - kasutajate puhul; new age'i hulka loetakse kõik psühhoteraapiad ning kõik loodusraviviisid; nii mõnigi kord loetakse ka vastu tahtmist new age'i pooldajaks iga inimene, kes on käinud homöopaadi juures või nõelravis või tunnetab pühadust looduses; new age’i riiulisse pannakse nii Arvo Pärdi muusika kui ka "Dhammachakkapavatanasutta" tõlge. Nõnda näib see termin kõikehõlmav, nagu tühi tähistaja, millele võib omistada mistahes sisu. (Potrata 2004: 366; Heelas 1996: 109; EUU 2010) 
Sotsioloog Colin Campbell pakkus 1972. aastal välja new age’i sünonüümina termini "kultusmiljöö". Lühidalt tähendab kultusmiljöö vastukultuurilisust, ketserlust, hereesiat. Campbell lähtus võrdleva teoloogia klassiku Ernst Troeltschi kolmesest jaotusest, mille järgi religioossed nähtused jagunevad kirikuteks, sektideks ja kultusteks. Kirik on Troeltschi jaotuses suur, väljakujunenud ja püsiv religioosne institutsioon. Sekt on väike, karmilt reeglistatud ja peaaegu kinnine kogudus. Kultus seevastu on Campbelli järgi puhanguline, vabameelne, teiste suhtes tolerantne ja ajutine, lausa efemeerne. Selle ajutisuse tõttu on kultusi keeruline uurida - nad on individualistlikud, lõdva struktuuri, ebamääraste piiride ja voolavate uskumustega. Campbell täheldas, et kuigi kultused aina tekivad ja kaovad, on hämmastavalt püsiv ning seega ka uuritav kultusi sünnitav keskkond: kultusmiljöö. Kultusmiljöö koosneb nende inimeste mõttemaailmast, kes ei ole rahul sellega, mida (kiriklikud) autoriteedid õpetavad. Kultusmiljöö on ühiskonna allhoovustele püsivalt omane "heterodoksne ja deviantne" - mitmeõpetuslik ja hälbeline - alternatiivsuse keskkond, milles tegutsejaid seob vastuseis ortodoksiale - õigeõpetuslikkusele. Campbelli järgi on kultusmiljöö oma heterodoksia tõttu enamasti ühiskondades uute ideede taimelava ja teistsuguse maailmapildiga ühiskondadest võõraste kultuurielementide vahendaja (Campbell 2002: 13-15). Hasso Krull (2012) leiab, et eestlaste usuleiguse tõttu on võimalik sama ideed "emantsipatoorse miljööna" kasutada ilma religioonile viitava kultuse sõnata. Marko Uibu (2016) kasutab aga väljendeid "spirituaalne miljöö", "vaimsuse miljöö" ja "uue vaimsuse keskkond”.

\section{Eesti statistikat}

Eesti Kirikute Nõukogu on iga viie aasta tagant tellinud sotsioloogilise küsitluse "Elust, usust ja usuelust" (EUU). Erinevatel kordadel on need küsimuste püstituse poolest oluliselt erinenud, näiteks 2015. aastal esitati mitmeid küsimusi kooseluseaduse kohta, mis varem pole päevakorras olnud. Küsimusele "Millal ja millega seoses te kogesite viimati pühaduse tunnet?" vastas 2015. aastal 1002 vastajast umbes kolmandik (307 inimest), et pole seda mitte kunagi tundnud ning teine kolmandik (303 inimest), et neil on seda raske öelda. Jumalaga seoses oli kõigist neist 1002 inimesest pühadust kogenud ainult 19 eestlast ehk 2,7\% 683 eestikeelsetest küsitletutest ning 12 muust rahvusest ehk 3,6\% 319 muukeelsetest küsitletutest. Oma seisukohana Jumala kohta väljendasid 2015. aastal neist 683 eestikeelsest küsitletust 369, et nad ei usu praegu ega ole kunagi uskunud Jumala olemasolu, 117 on alati uskunud, 65 olid oma usu Jumalasse kaotanud ning 70 mitteuskumisest usku pöördunud. (Jõks 2016) 
Eraldi uut vaimsust puudutavat küsitluse osa 2015. aastal ei olnud, kuid see kuulus 2010. aasta EUU küsitlusse ja sisaldas isegi nii jooga kui ka Tai massaaži mainimist. Need küsimused koostati kirjeldavatena, et vältida new age’i väljendi negatiivset kuvandit. (Altnurme 2012) Tervikuna keskendus uuring eelkõige raamatupoodides pakutava rikkaliku valikuga uue vaimsuse kirjanduse lugemusele. New age'i pooldajateks loeti Eestis neid vastajaid, kes olid lugenud raamatuid sellistelt autoritelt nagu Osho, Anatoli Nekrassov, Neale Donald Walsh, Eckhart Tolle, Luule Viilma, Rhonda Byrne, Bruce Lipton. Et psühholoogilise vmt kirjanduse vastu huvi tundmine ei saa mitte kuidagi välistada inimese enese-identifitseerimist kristlase, moslemi või ateistina, võib lugemuspõhine hinnang Eesti rahvastiku jagunemisele kultusmiljöö ja religioonide vahel anda tugevalt nihkes arvulised lõppandmed.

Uuringus küsiti ka seda, kuidas vastajale sobivad väited (EUU 2010):

1. Ma usun üksnes iseendasse ja oma võimetesse.

2. Minu vaimne eneseteostus käib kultuurist osasaamise kaudu.

3. Usk Jeesusesse mõtestab minu elu.

4. Ma usun vaimsesse enesearengusse selles mõttes, et teadlike enesesisenduste ja vaimsete praktikate abil on võimalik muuta iseennast, oma elu ja maailma enda ümber.

5. Pean pühaks esivanemate põlist pärandit ja loodust ning järgin võimalusel vanu rahvausu kombeid.

Neljandale küsimusele - enesesisendustega maailma muutmise uskumisele jaatavalt vastajaid hinnati uuringus uue vaimsuse esindajaiks: täiesti nõus $14,3 \%$ eestlastest ja 8,9\% mitte-eestlastest. Kolmandale väitele jaatavalt vastajad loeti kristlasteks: täiesti nõus $4 \%$ eestlastest ja $6,2 \%$ mitte-eestlastest. Viienda väite jaatajaid nähti maausulisena: täiesti nõus $21,3 \%$ eestlastest ja 13,6\% mitte-eestlastest (Altnurme 2012). Et kultuurist võib eneseteostust leida nii kristlane, moslem kui ka ateist, on väite nr 2 tõlgendamine ateistina problemaatiline.

Samuti loeti EUU 2010 järgi uue vaimsuse vaadete pooldajateks kõik vastajad, kes olid osalenud nn vaimset enesearengut toetavates tegevustes nagu jooga, mediteerimine, vabastav hingamine, reiki, sütelkõnd või otsinud abi sensitiivi, teadmamehe või -naise juurest või kasutanud mõnda alternatiivmeditsiini teenust, nagu homöopaatia, nõelravi, ajurveeda, Tai massaaž. Sellekohased küsimused oli paigutatud alajaotusesse, mis algas küsitleja jaoks ettekirjutatud sissejuhatava lausega: "Räägime nüüd uus-usunditest." Küsitluse analüüs oli üles ehitatud nii, nagu sõltuks Tai massaaži ja kõigi muude loetletud raviviiside tõhusus (= kas sai abi?) sellesse uskumisest. See nimelt on tõlgenduslik erinevus, millega ei ole nõus ei mina omaenese kogemuse põhjal ega minu küsitletud, kelle elulugudest pärinevad tsitaate esitan käesoleva artikli 
lõpuveerandis. 1009 vastajast (684 eestlast, 325 mitte-eestlast) olid kasutanud alternatiivmeditsiini 114 inimest ehk 11,3\% (sh 75 eestlast ja 39 mitte-eestlast), neist 73,8\% said sellest abi (Altnurme 2012). Mina ei pea õigeks hinnata vastust "jah" küsimusele: "Kas te saite sellest abi?" inimese religioosselt uue vaimsuse uskujaks määratlemise diagnostiliseks kaalukeeleks, sest objektiivselt saab lihaste tegelikust pikendamisest ja rühi parandamisest tulenev kasu aidata objektiivse valuaistingu vastu nii tõsiusklikku kristlast, juuti, moslemit kui ka veendunud ateisti.

Joogaga tegeles 48 inimest 1009 vastanust ehk 4,8\% (sh 32 eestlast ja 16 mitte-eestlast), lähedane sõber või pereliige tegeles joogaga 162 inimesel ehk 16\% vastanutest (sh 118 eestlasel ja 44 mitte-eestlasel) ja koguni 31,8\% joogaga seni mittetegelenud eestlastest on mõelnud tulevikus joogaga tegelema hakata (Altnurme 2012). Suurem osa minu vastanuist, kes on joogat teinud, suhtub sellesse kui hommikvõimlemisse, st materialistlikku spordialasse, ning pole üldse teadlik šivaismi religioossetest pretensioonidest jooga leiutamisele.

\section{Enesenägemused}

Minu empiirilise uurimistöö valimi hulka ei kuulunud ainsatki inimest, kes ise enda kohta ütleks new age’i või uue vaimsuse järgija. Küll aga kuulus Tai massaaži oskavate massööride hulka kristliku kiriku liikmeid - juba mu 2011. aastal kaitstud magistritöös kasutatud 11 intervjuu kaks vastajat kuulus ametlikult luterlikku kogudusse ning veel neli tunnistasid end kristlaseks ilma konfessionaalse ja juriidilise osaduseta. Töö jätkamisel võin paleti terviklikkuse huvides ka teadlikult minna küsitlema just erinevate kirikute liikmeid (eriti alternatiivmeditsiini klientuuri ja selles osas täiesti teadmatuses olevaid vastajaid otsides).

Lindistatud elulugude jutustajad ei ole nõus sellega, et komplementaarmeditsiini tegevusala määratleb nad automaatselt new age'i nimelise uue religioosse liikumise osaks. Intervjuudes on new age'i sõnapaari suhtes väljendatud lausa vaenulikkust:

New age on sõimusõna! New age on minu arusaamise järgi... nagu Haljand Udam ütleb, et see on agulinooruse ajaviide... ja raamatupidaja... New age on see, et vanast kultuurist on välja rebitud mingisugune väikene element ja siis selle peal elatakse! Kõik see sodi-raamatud, eneseabiraamatud, mis ilmuvad... ma ei teagi nende nimesid ja ei tahagi teada! (m 1947; ERA DH 311) 
Samas on massaaži õppimise vastu olnud paljudel aastatel nii laialdane huvi, et selle sotsioloogilise ajendina võib kirjeldada ka new age’i diskursusesse kuuluvat enesearengu paradigmat (Altnurme 2006; Heelas 1996; Potrata 2004). Ajakirjanikuna erinevaid kursusi külastav intervjueeritu (B) väitis, et "Eestis oleks võimalik igas aastas järjest kõik 365 päeva erinevate teraapiate ja raviviiside kursustel käimisega ära täita!" (n 1962, ERA DH 290). Ühes kuuest konkureerivast koolist juba ligi kümme aastat töötanud õpetaja (E) imestas, kuidas lisaks kooli statsionaarsetele ja kaugõppe-õpilastele nii palju inimesi aastast aastasse käivad õhtustel ja nädalavahetuste kursustel: "Kust nad tulevad? Kõik inimesed Eestis peaksid niiviisi juba massöörid olema!" (m 1960; ERA DH 293), ehkki see oli öeldud mitte ainult Tai massaaži, vaid ka Rootsi klassikalise massaaži, Jaapani massaažide, Hiina tui na ja kõigi muude pakutavate kursuste kohta. Zygmunt Bauman on postmodernismi tunnuste hulgas pakkunud välja ka "uute aistingute kogumise" (Bauman 1995: 111), samuti pole mingit takistust mängida mõttega, et kursustele tulijaid käivitab just vajadus kehatehnika kaudu millegi vaimse-müstilise kogemiseni jõuda (Mauss 1934: 23).

Tai massaaži nimetatakse laisa inimese joogaks - see sisaldab jooga-laadseid venitusasendeid kliendi seisukohalt passiivselt kogetavana, väljastpoolt "ära võimeldud" olemisena. Eestis üleüldse on ka tavalistes terviseklubides nii palju erinevaid joogatreeninguid pakkumisel, et India joogakoolide õpetajad, näiteks Khaustub Desikatchar Chennaist, on olnud väga imestunud ja ühele intervjueeritule isegi otsesõnu öeldnud, et (rahvaarvuga võrreldes) Eestis tehakse joogat palju rohkem kui Indias (n 1956, ERA DH 306). Üks mõtlemisväärne nüanss lisandub veel varasemast NSV Liidu poliitajaloost: jooga oli seoses budistide tagakiusamiskampaaniaga NSV Liidus alates 1973. aastast keelatud (m 1936, ERA DH 296). Seepärast on religioonisotsioloogilise või psühholoogilise loogika järgi võimalik väita, et dissidentlik maine tegi jooga kommunistliku normi mõttes hälbelise vastukultuuri või kultusmiljöö orgaaniliseks osaks, mida ta võib-olla muidu poleks olnud. Seega võib see jooga salapärane, vastukultuuriline aura üldise mentaliteedi mõttes laieneda tänapäeval ka Tai massaaži passiivsete joogavenituste kogemusele, andes sellele teatud vaimsustatud värvingu ka ilma selleta, et klient oleks üldse teadlik selle manuaalmeditsiini budistlikust päritolust.

Intervjueeritud ise olid Tai massaaži seosest budismiga teadlikud väga erineval tasemel - oli neid, kes olid õppinud Tais ja sealseid rituaalseid praktikaid kaasa teinud või jälginud (ERA DH 290, 292, 288, 293, 294), ja neid, kes olid sellest kuulnud vaid õppeprotsessi käigus (ERA DH 297). Üks kõige esimesi lülisid Tai massaaži Eestisse jõudmise ahelas (C) mainis nuad bo rarni budistlikku tausta sellise hoiakuga, nagu oma kaupa reklaamiv kaupmees, rõhutades 
eriti tõhusust ja diskreetsust võrreldes lääneliku haiglaprotseduuriga, sest Tai massaaži tehakse läbi riiete:

Tai massaažis on nii palju iidset tarkust! ...budalikku tasakaalu, budistlikku tasakaalu, et ta peab sobima kohe inimesele, kes ise on nagu selline sportlike eluviisidega ja oskab asja hinnata... Ja muidugi-igal pool võimalik teha, kompleksivaba, selles mõttes, et klient ei pea riidest lahti võtma... Ja see kestev enesetunne... massaaži puhul, mis teistel massaažidel on... on nii ja naa... Tai massaažil, noh, kui oled korralikult ära teinud 2,5 tundi... see, et mõju nädala kestab, ei kahtle keegi... Ja ta oli uudne, seda ei õpetanud Eestis mitte keegi tol ajal... eks?! (m 1954, ERA DH 288)

Inimestega, kes Eestis loevad end budistideks, Tai massaaži kogukonnal sidemeid ei ole (ERA DH 298). Konkreetsete budistlike tekstidega on antud valimis küsitletutest tuttavad vaid kõrgharidusega inimesed, kes on Tartu Ülikoolis käinud piisavalt ammu, et puutuda kokku orientalistikaringiga (n 1962 ERA DH 290, m 1956 ERA DH 302-1). Nii ongi Tai massaaži algne tähendus budistliku teekonna osana atraktiivne nüanss vaid haritumatele intervjueeritavatele.

Samas see, mida väitis Friedrich Schleiermacher 1822. aastal oma teoses "Kristlik usk" (Schleiermacher 2012), et religioonil on oma iseseisev eluruum tunne -, et religioon on igavikust absoluutse sõltuvuse tunne ja sellisena mõtlemisest täiesti sõltumatu, tuleb ebamääraste uitmõtetena esile ka minu poolt kogutud empiirilises materjalis:

Minu jaoks jäi sealt kõlama see... niisugune inimlikkuse, ja mingi sellise tavaintelligentsist veel laiema... noh, tollal ei teadnud ma veel teistest terminitest... ja ütleme midagi jumalustest ja ei olnud ju kokku puutunud niisuguste asjadega, isegi horoskoobid olid ju praktiliselt keelatud ja sai ju paljundatud ainult, et saaks lugeda midagi niisugust asja, noh, see kõik oli ju teine aeg... et ma tajusin seda kui mingil inimlikkusel, armastusel ja väga sügaval intelligentsusel põhinevana, aga millel oli veel mingi nüanss, vot, see nüanss, mis mind võlus... mida ma niiviisi magusa valuna tajusin... ja nü̈̈d ma olen tagantjärgi jõudnud ise Jumalani, või noh, Budani... kuidas see peaks... minu jaoks see nimi pole üldse oluline, ma loen ennast väga sügavalt usklikuks inimeseks, aga ma ei ole seotud ühegi religiooni, ühegi kirikuga... Ma ei näe ühtegi põhjust, miks peaks minu ja Looja, ehk algallika, vahel veel keegi olema... ja mulle väga meeldib kunagine Linnart Mälli termin, kui ta käis sanskriti tekste endal lahti rääkimas, mis ta just tõlkind oli... Salme Kultuurikeskuses, kus ma käisin keskkooli ajal tema loenguid kuulamas, juba enne Tartu ülikooli - arukas energia! Arukas energia, see, mis on loonud universu- 
mi, mis loob universumit kõik see aeg... minu jaoks on täiesti nonsenss rääkida Suurest Paugust, kus kõik tekkis, see kõik on kõik see aeg olemas olnud, sest aega ja ruumi pole üldse olemaski... Sealt me läheme juba muude tajudeni edasi... Kõik see on kogu aeg olemas ja praegu ka loob kogu aeg igas hetkes uuesti... ma näen ja mõistan seda oma südamega, just südamega, sest siit [mõistusest/peast] pole mitte midagi võimalik aru saada... siit võib aru saada, et kui paned näpu koogi sisse, siis näpp saab kohupiimaseks, see on selline reaalne, väga arusaadav asi... siis lähed, tõused püsti ja lähed pesed puhtaks käe, mõistuspärane inimene, eks ole! Sealt see aruka energia mõte - vaat see on see, mis sealt raamatust hakkasin tajuma alles hiljem. Nii, keskkooli ajal käisin siis Mälli kuulamas Salme Kultuurikeskuses, sinna võttis kaasa üks ema kolleeg, kirurg, kes on praegu kirikuõpetaja, kui ta üldse elus on, ta oli väga vana mees juba tollal, Jüri Raudsepp, [---] tema võttis mind kaasa Mälli kuulama, ja Tartu ajal, muidugi, kui ma vähegi sain, siis ma kuulasin Mälli, siis ma kuulasin Aarmat palju... ja mida sai, sai raamatuid loetud... (n 1962, ERA DH 290)

Schleiermacheri arvates teeb religioon õnnelikuks, õnnelikud inimesed saavutavad õnnetutest rohkem, sest usklikkus on kasulik eluhoiak, kristlased liiguvad kultuuri ja progressi avangardis, sest usk toetab eesmärke, mille annab usklikule riik ja kultuur (Schleiermacher 2012). See hoiak näib aga viimase saja aastaga olevat vähemalt Eestist täiesti kaduma läinud.

\section{Energia küsimus}

Kultusmiljöö (= new age'i ehk uue vaimsuse) üheks kriteeriumiks religioonisotsioloogias peetakse viitamist oma mina sisemisele arengule või näiteks sõnade "energia" või "tervendamine" kasutamist oma jutus. Ka Eestis Tai massaaži oskavate inimeste hulgas on need mõisted käibel. Tai massaaži õppinute hulgas on üksikuid, kes panevad kõik ühte patta näiteks Luule Viilma laadis new age'i väidetega, et oma mõtetega me mõjutame oma tervist (ERA DH 302-2) või Hiina nõelravi kanalite ja yin-yang teooriatega (ERA DH 301, 292). Üks intervjueerituist, kes oli Eestis esmakordselt Tai massaaži õppimise ajaks juba aastaid käinud Hiina nõelravi Nei Jing'i koolis Haapsalus (D), püüdis Hiina nõelravi teadmiste põhjal ise lühikursuselt õpitud Tai massaaži veel rikastada:

Siis mulle tundus nagu... et selle Nei Jingi baasil, et sealt on nagu midagi puudu... ja siis ma panin nagu Hiina meditsiini ja selle kokku, et ma tegin täiesti enda... enda massaaži nagu! Noh, nagu selles mõttes, et ta 
oli küll nagu valulik tulema, selles mõttes, et ega ta nagu väga kergelt ei tulnudki ju... ja noh, sealsamas ka see valusalt tulnud laps, et see on ju nihukene väga armas, et... et siiamaani ma mingeid asju kasutan nagu sealt. (m 1968, ERA DH 292)

Üks vastajaist, kes igapäevaselt töötab riiklikus haiglasüsteemis, on pragmaatiliselt veendunud, et arusaamatutest sõnalistest seletustest hoolimata nõelravi ja punktimassaaži aluseks olev vana-hiina yin-yang energiakanalite õpetus vastabki reaalsele anatoomilisele tõele:

Ikkagi tuleb neid kanaleid taga ajada, selles mõttes, et kõik asjad toimuvad ju ikka mööda mingeid nähtamatuid kanaleid! Et siit mingi, küll sapipõie ja ma ei tea mille kanalid jooksevad ja siin on mingid punktid, mida mõjutades midagi ikkagi toimub. [---] Mina pigem arvan, et see ei ole lihtsalt triip! Ma ei tea, kas ma olen naiivne, või olen ma loll, või mis iganes, aga... aga ma olengi üsna veendunud, et see ongi nii! Sest minu jaoks ei ole vaja seda, et mulle näidatakse röntgenpilti ja öeldakse, et näed, need triibud! Mulle piisab sellest, kui inimesed on seda aastatuhandeid teinud ja see toimib! Järelikult - seal midagi on! Et, noh, selles mõttes ma olen enam kui veendunud, et ongi olemas! (n 1978, ERA DH 301)

Samas ka see vana-hiina energiakanaleid anatoomiliseks tõsiasjaks pidav haiglatöötaja ei pea ühtegi massaaživõtet usupõhiseks ning näeb just aastasadade pikkuses ajaloos väga ergonoomiliseks lihvitud budistliku Tai massaaži tehnikatest praktilist kasu oma tänastele patsientidele:

Minu kogemus on näidanud, et isegi... kuidas ma ütlen... nendele, kellel on spastiline halvatus, mis iganes - et näiteks Tai venitused tõsiselt hästi aitavad. Et tai on selline hästi rahulik - ja... ja... vajutad ja venitad ja vajutad ja venitad ja... sihuke... kuidas ma ütlen... hästi pinges lihastele väga hästi aitab! Et... noh... ma ei oskagi seda seletada... aga see ongi ikkagi... et vaatad inimest enne, kui sa talle soovitama hakkad, et mis... mida... [---] Sa proovid ikkagi siis, kui sa arvad, et sellel on mõtet... et noh, mitte nii, et igale inimesele ütled, et homme me nü̈̈ teeme mati peal massaaži! [---] Inimesed on erinevad, aga enamus, kes on tulnud mati peale, need on ka jäänud... kas siis vahelduvalt käima - nii mati peal kui laua peal-või ainult mati peal. Et noh, kes on ühe korra proovinud, need on reeglina ikka jäänud rahule. Aga, noh, neid inimesi on nagu vähe... ega ma mingeid 60+ tädisid, kellel on vahetatud puusaliigesed, ega ma neid siia lükkama ei hakka põrandale pikali... et eks seda peab ikka... ma ütlen, noh, et vaatad peale ja... mõtled, mis on nagu mõttekas... sest väga palju võib neid võtteid ju - nii tai venitusi kui yumeiho'st igasuguseid 
vajutusi ja venitusi - ju tegelikult saab väga palju laua peal kasutada ja väga paljusid ma kasutangi laua peal. (n 1978, ERA DH 301)

Massööridest, kes peavad oluliseks inimese füüsilise tervise seost tema eluhoiakutega, rühiga, hingamisega, jätkuva võimlemisega, päris mitmed püüavad teha oma klientide hulgas seda teoreetilist selgitustööd, mida on nimetatud ka misjoneerivaks klientkultuseks (Lyra \& Altnurme 2004), kuid nad kogevad sageli ka seda, et koduse hommikvõimlemise programmi kaasaandmisest pole tihtipeale mingit kasu:

ma olin nagu väga oma nahal järgi proovind seda, et siis kui inimene ise tahab endaga tööd teha, ja see on see, mida mina praegu terapeudina inimestega teen, sa saad teda aidata teeotsa peale, edasi peab ta loomulikult ise minema. Aga alati jääb see kontingent, kes käib kehaga autoremondis, ja heidab sulle kas siis lauale või põrandale, mina töötan põrandal, eks ole, et tehke mind korda, ja noh, see on tema valik. Ei saa, ei ole mõtet põdeda sellepärast, et näe, ma andsin talle nii head soovitused, miks ta nü̈̈d nii ei tee, tema keha ja tema hing, tema tervis, tema elu... aga ma saan anda need soovitused. (n 1962, ERA DH 290)

Mõne raviviisi (näiteks reiki) juurde käib tõepoolest palvetamine "jumaliku" energia vahendamiseks. Samas ei pea massööri jaoks sõna "energia" olema alati usulise mõiste tähenduses, pole välistatud, et selle kasutaja on samal ajal ateist. Massaažis mõjutatavate jõujoonte olemust saab kujutleda ülimalt füüsikaliselt-mehhaaniliselt: nagu pingule tõmmatud vibunööri elastsust või kangi jõuõlgade tööpõhimõtet. Ka keha seesmisi energiaid on võimalik soovijail ette kujutada täiesti religiooniväliselt - näiteks jooga pranayāma väide õhust energia saamise kohta sobitub igati kütuse põlemiseks vajalike tingimustega: ehkki me oleme harjunud rääkima, et põlemisprotsessis saadav soojusenergia on pärit kütuse kütteväärtusest, mis vabaneb hapnikuga ühinemisel, siis inimorganismi lihaste puhul, kus kütteaine ATP (adenosiintrifosfaat) on lihastesse juba varasemalt ladustatud, on selle "põlemisprotsessiks" (lagunemiseks adenosiindifosfaadiks, ADP-ks) tarvis just nimelt hapniku juurdevoolu, mida saadakse nina või suu kaudu sissehingatavast õhust. Enamik massööre endale siiski nii täpselt lahti ei seleta, mida sõna "energia” nende kasutuses tähendab.

\section{Vastasseis riigimeditsiiniga}

EUU 2010 analüüs peab kõike riigimeditsiini-välist usul põhinevaks platseeboks, esitades küsimusi ülesehitusega: "Te mainisite, et olete käinud joogas / psühholoogi juures / homoöpaatias / Tai massaažis. Kas te saite sellest 
abi?" ning lugedes vastust "jah" $72 \%$ vastajatelt (näiteks) tõenduseks, et $72 \%$ "usub" joogasse/psühholoogi jne. (Altnurme 2012) Midagi samalaadses meeleolus võib välja lugeda suurte ajalehtede uudislugudest korallipuru/sooda vmt joogivette panemise, soolenugiliste välja ajamise soovituste jpm kohta. Näib, et farmaatsiatööstuse ravimitele ja invasiivsele kirurgiale toetuv koolimeditsiin on meie ühiskonnas tõepoolest ortodoksia, mille kõrval loetakse peaaegu ketserluseks tervise mõjutamist käeliselt, mittefarmakoloogiliselt ja mitteinvasiivselt. Täiendmeditsiinis tegutsevate inimeste nägemus iseendast sisaldab aga palju rohkem riigimeditsiini aluseks oleva materiaalse lääneliku hariduse täielikku arvestamist ning sinna millegi sügavama ja väärtuslikuma lisamist kui ametlik meditsiin ja meedia neid väljastpoolt on nõus tunnustama.

ükskõik, mis ravi see on, alternatiiv - mina üldse seda alternatiivi sõna ei armasta, sellepärast et see oleks just see nagu marginaalne nähtus minu jaoks on see aastatuhandeid vana ja veel vanem kui Hippokratesest välja kasvanud see klassikaline meditsiin. Ja kui üldsegi süveneda... selle Hippokratese... ja noh sellesse aega, siis seal on kõik need asjad olemas, mis on tänapäeval nii-öelda alternatiivi paigutatud... ainult need on kuidagi ära unustatud. Vaadatakse... Selektiivne mälu ja selektiivne valimine, eks ole, noh, valikute tegemine selle põhjal: ma tahan seda mäletada, sest need on meie juured... aga et tegelikult on neid terve pusa neid juuri seal all, see kuidagi ununeb ära nendel tohtritel väga sageli. (n 1962, ERA DH 290)

Arstiteaduse eelarvamuslikkust alternatiivmeditsiini suhtes, millest ka arstid ise on teadlikud, ilmestab ühes kogutud eluloos (D) mälestus perestroika aegadel Olümpiapurjespordikeskuses õpetanud spordiarsti Toomas Savi nõuandest, et rääkija ei tohiks minna õppima arstiks, kui ta tahab jätkata selle uurimisega, mida ta on teada saanud massöörina:

Inimene, kes on lõpetanud Tartu Ülikooli arstina... ta teab kõike, kuidas on... et see asi on nii, sellele järgneb see... aga siis läheb üks kümme aastat mööda, ja siis ta hakkab aru saama, et need asjad tegelikult ei ole nii... aga siis on juba midagi muud hilja hakata õppima! (m 1968, ERA DH 292)

Samale intervjueeritule, kui ta soovis 1990. aastatel kirjutada füsioteraapia diplomitöö, tuginedes Hiina nõelravi teooriatele, olevat tookordne Tartu Ülikooli kehakultuuriteaduskonna füsioteraapia kateedri juhataja vastanud: "Ainult üle minu laiba!" (m 1968, ERA DH 292)

Kitsendades arutluse neile vähestele üsna kategoorilistele kontseptsioonidele - tableti-skalpelli-meditsiin kui ortodoksia ning täiendmeditsiin kui selle ortodoksia suhtes deviantne heterodoksia - näitavad nii Saar Poll OÜ 
statistilise küsitluse EUU 2010 numbrid kui ka minu kogutud eluloointervjuude narratiivid, et kliendi enesetunde heaks toimib see heterodoksia üsnagi edukalt: tervist saab edukalt muuta vahenditega, mida koolimeditsiin ei tunnusta. Sealjuures ei tähenda see sugugi, et mu uurimisväljal väidetaks, nagu püüaks Tai massaaži tegev massöör "muuta iseennast, oma elu ja maailma enda ümber" kõigest/peamiselt "teadlike enesesisenduste ja vaimse praktika abil” (EUU 2010). Tai massaaži ja jooga mõju näevad nende kehatehnikatega tuttavad inimesed eelkõige lihaste ja liigeste füüsilisest liigutamisest, venitamisest, gravitatsiooniväljas asetseva keha hoiaku / rühi parandamisest lähtuvalt, mitte vaimsetest enesesisendustest tulenevana.

Kogutud eluloointervjuude hulgas leidub ka komplementaarmeditsiini mõne teise külje sisenägemust valgustavaid lõike. Ka nende puhul saab leida kliendi "usust" sõltumatuid reaalseid toimimisfaktoreid. Näiteks ühe legendaarse rahvaravitseja lähikondse sõnul "suudavad kõik pereliikmed metsast üles leida peres tavaliselt korjatavad ravimtaimed, kuid see jääb pigem n-ö suulise pärimuse jäljendamise tasandile: "Mu ema või isa tegi nii ja see toimis ja see oli hea ja ma teen ka samamoodi" (n 1971; ERA DH 404). Aga sensitiivi-kuulsusega inimese klientidele omapäi samal tasemel abi nad ei suudaks pakkuda, sest neil puudub "keemiku ja bioloogi" haridus (!!!) koos teadmistega kaasaegsest farmakoloogiast ja biokeemiast ning antud inimese filigraanne oskus vereanalü̈̈si vastusest ja kodumetsa taimedest "keemilisi elemente lugeda ja kokku sobitada" - kui tsiteerida täpselt selle inimese sõnu, kes on aastakümneid saanud kodus pealt näha sensitiivi abiandmise tehnilist poolt.

Teine inimene, kes ise naljatamisi nimetab end küll Soome nõia õpilaseks, leidis toitumis- ja loodusravid eelkõige seepärast, et 1987. aastal haigestus ta seitsmeaastane tütar reumatoid-artriiti: "Ma jooksin läbi kõik arstid, ma andsin talle nii palju medikamente, nagu neid lapsele välja kirjutati - ja siis ma nägin, et kasu polnud mitte millestki!" (n 1961; ERA DH 400) 7,5 aastat taimetoitlust suutis tütre teismeliseea jooksul ta haigust veidi kontrolli all hoida, kuid ema tajus kasututest ravimitest põhjustatud kahju tütre tervisele. Juba pärast laste täiskasvanuks saamist massööriks õppides viis ligi 20 aastat liigsete ravimite pärast muretsemisest tekkinud huvi aadrilaskmise vastu ema saama lisakvalifikatsiooni Soome Verekuputeraapia Assotsiatsioonist. Vere kehast välja laskmisega tervise parandamise otstarbel organismi puhastamine kui omaette raviviis ulatub oma juurtega vähemalt Bütsantsi. Skandinaavia viikingid ja vabatalupojad ravisid end sajandite jooksul puhtaks keedetud õõnsate lehmasarvedega, tänapäeval on aga Soome "kuppari-mooridel" osaliselt kummist ja osaliselt klaasist spetsiaalsed kupud, millesse on juba sisse ehitatud tillukesed lõiketerad. Nüüdseks on too intervjueeritu jõudnud töö käigus kogeda, et vastavalt eelnevale traumale, haigusele, elustiilile, kasutatud ravimitele 
jmt võib kehast saunas laiendatud kapillaaride imetillukeste haavade kaudu eemaldatav veri oluliselt erineda lõhnalt, värvilt, tekstuurilt, tüübilt. Näiteks bronhiaalastma haigetel eraldub veri "abaluude lähedalt kopsupiirkonnast nagu kiletükke sisaldavana", suitsetajatel on tihti "tohutult paksudes klimpides" ja pika ravimikuuri teinutel "veri haiseb õudselt - täpselt medikamendi haisuga ja on tume-tume" (n 1961; ERA DH 400). Vaatamata verekuputeraapia võikale imidžile on see kõik tema sõnul väga seletatav ("selles ei ole mingit nõidust!") ning teadlikult usub ta kõigest "iseendasse ja oma otsustesse", mis EUU 2010 küsitluse järgi oleks ta otsesõnu ateistiks kvalifitseerinud (Altnurme 2012).

Samalaadset "õigeõpetuslikkuse" usaldamatust (nagu ametlike religioossete institutsioonide suhtes) võib Eestis kohata ka ametliku meditsiinisüsteemi vastu - lisaks pettumusele farmaatsiatoodete ravimissuutlikkuses ilmneb vahel tõrksus ka patsiendiks olemise kui elus valida võidava sotsiaalse rolli suhtes. Pealkirjas kasutatud emotsionaalne hüüatus "Ega ma arsti juurde ju ometi ei lähe!" on pärit 28. veebruarist 2017 ühelt nooremapoolselt naiskliendilt erameditsiini arstikeskuse massaažikabinetis ta vabast arutluskäigust oma mõningate terviseprobleemide üle. See ei lõppenud sugugi teadliku pöördumisega alternatiivravi võimaluste poole, vaid millegi meie netiajastule hoopis iseloomulikumaga: “Doktor Google aitab!” Võrguühiskonna ja digipärismaalaste põlvkonna selge eelistus saada oma küsimustele vastused impersonaalselt, ilma teise elusa inimese ees abisaaja positsioonile asumata, viitab taas alusväärtustest ilmnenud enese üle ise otsustamise ehk autarkia (= alandlikkuse vastandi) kõrgele väärtustamisele. Googeldamist kasutavad patsiendid nii enne kui ka pärast arstivisiidil käimist ning mitmed õpetused ja õpetajad seda ka selgesõnaliselt soovitavad oma seisukohti ja väiteid puudutava lisainfo hankimiseks. Ka sama arstikeskuse üks perearst jõudis 2017. aasta veebruaris väljaspool lindistamisvestlust kurta oma igapäevatöö ühe suurima probleemina patsientide kalduvust internetist "endale juba kolme erineva diagnoosi hirmud ajusse istutada".

\section{Idastumine ja purunenud transtsendentsus}

Seesama Colin Campbell, kellelt pärineb mõiste "kultusmiljöö", pakkus veerand sajandit hiljem, 1997. aastal välja ka mõiste "Lääne idastumine" (Easternization of the West). Ta analüüsis inglise keele seletavate sõnaraamatute näitel sõnavara muutusi 20. sajandi jooksul klastermeetodil ja avastas, et enamik uusi sõnu kuulub peamiselt kahte klastrisse: ökoloogia ehk roheline mõtteviis ja psühholoogia ehk eneseteadlikkus (Campbell 1999: 35-48). Tundes hästi võrdlevat teoloogiat ja religioonisotsioloogiat nägi Campbell nende kahe klastri 
ühisnimetajana hinduistlike-budistlike maailmataju kontseptsioonide ülevõtmist. Näiteks näeb ta loomaõigusluse juuri hinduismi taassündide usus - et igas loomas peitub kunagi varem inimene olnud ja kunagi hiljem taas inimeseks muutuv hing - samas kui kristlus loomadele mingeid õigusi ei laienda, sest Esimeses Moosese raamatus seatakse Aadam loomade üle täievoliliseks isandaks. Samal kombel on näiteks "teadvuse" mõiste budismi sõltuvusliku tekkimisahela kolmas lüli (pärast rumalust ja väljamõeldisi), mille ümber emaüsas hakkab moodustuma lapse keha; judaismi-kristluse tüvitekstides seevastu tähendas "hea ja kurja tundmise puust söömine" pärispattu, mille eest määrati inimestele karistuseks paradiisist väljaajamine, surelikkus ja kõik maised kannatused. Ligi 2000 aastat läänelikkust valitsenud "patu ja kohtumõistmise" paradigma (kõikvõimas Jumal versus patune inimene) on tänaseks vahetunud varem Idasse kuulunud "inimese ja looduse ühtsuse" paradigma vastu [tat tvam asi (तत्त्वमसि) = see sina oled $=$ jumalik alge sisaldubki minus endas]. See protsess algas 19. sajandi teisel poolel - kõige hiljem 1875. aastal religioonide võrdlevaks uurimiseks mõeldud teosoofiaühingu rajamisega New Yorgis. Campbelli järgi ilmneb idastumine kogu läänemaailmas nii rohelises mõtteviisis kui ka psühholoogilises sõnavaras täiesti valdavana pärast 1960-1970. aastate hipiajastu vastukultuuri, mille aluspõhjaks olid ka freudism, sürrealism ja eksistentsialism.

Kõik see, mis Campbelli arusaamas kuulub kas kultusmiljöösse või Lääne idastumisse, on Bronislaw Szerszynski järgi kaasaegse religioossuse põhiomadused. Kogu maailm on tema väitel jõudnud teisele poole seda, mida Szerszynski nimetab "monoteistliku religiooni pikaks kaareks". Ratsionaalne valgustusajastu purustas selle Karl Jaspersi (1955) kirjeldatud "transtsendentse telje", mis rajati "teljeajastul" (6. saj eKr - 4. saj pKr). Telje transtsendentne kõrgus andis inimkonnale võimaluse mõtiskleda materiaalse empiiria üle. Siiski pole inimolendil võimalik pühadusest täielikult lahti saada ka mõistuse jõul kirikute ja jumalate purustamisega. Vaatamata filosoofia ja teaduse võidukäigule on inimesel endiselt vajadus midagi pühaks pidada. Kui varem toiminud institutsioonid on kaotanud usutavuse, siis vajab see pühadustunne mingit uut struktuuri, kuid ei lakka eksisteerimast. Institutsionaalsetest ankruköitest vabastatud religioossed sümbolid ja käitumisviisid on muutunud Szerszynski järgi vabalt triivivaks kultuuriliseks ressursiks. Midagi olemuselt religioosset ilmneb erinevates eluvaldkondades, kus seda sageli ära ei tunta - näiteks meditsiinis, hariduses või spordis. Tänapäeval leidub purunenud transtsendentsuse kilde kõikjal meie ümbruses, nii looduses kui ka tehnoloogias, nii keskkonnas kui ka inimkehas. Tänane nn postmonoteistlik inimene on sunnitud oma vaimsuse ise individualistlikult neist kildudest kokku panema. (Szerszynski 2005: $15-16,26,168-178$. 
Kui Maussi järgi võib kehatehnika olla ka "bioloogiline vahend, astumaks suhtlusesse Jumalaga", siis mõne intervjueeritu isiklikus kogemuses on vaimsete otsingute, leidmiste ja tagasiside kogemusi. Neist vaid üksainus (B) arutleb eluloointervjuus väga pikalt Jumala ja usu üle, tema silmis on Tai massaaž eelkõige tema enda Jumala otsimise tulemuslik lõppfaas:

Ma olen süvameditatsioonis olnud terve päeva, ma olen võimelnud terve päeva, ma olen keskendunud olekus olnud terve päeva - no mida veel tahta?! Mida üks amet võib veel inimesele rohkem anda?! Aga ta annab kõiki neid asju, mida ma tahan, see ongi minu, noh, vaimne kasvamine! Jõuda veel sügavama usu tasandile, veel sügavama kontaktini Jumala, looja, Buda, aruka energiaga, kuidas seda iganes algallikat nimetada, noh, see, mis universumit loob, mis meid on loonud. (n 1962, ERA DH 290)

Rohkem räägivad vaimsetest ja usulistest otsingutest intervjueeritud, kes on ühtlasi joogaõpetajad ning seetõttu nähtavasti harjunud oma vaimseid püüdlusi õpilaste tarbeks sõnastama.

Jooga õpetab elama südame ruumis. Kui mul on siit [südamest] olemas vertikaalne suhtlus, siis mind ei häiri nii palju see, mis toimub minu igapäevases horisontaalses suhtluses. (n 1956, ERA DH 306)

Intervjueeritutele ei ole idamaine kehatehnika tunnetatavalt "kultuuride dialoogi" osa, see ei ole nende silmis "teine". See on midagi ehtsat, loomulikku, nagu oma juurte juurde tagasi jõudmine - "meie" liigub sisetundes tegevusala väärtuskategooriatesse.

Sümboleid ja mõtlemise kategooriaid, mida oma töös rohkem kasutatakse ja oma õpilastele seletatakse, hinnatakse nende lihtsuse, filosoofilise üldistusjõu aspektist. Juhul, kui need on pärit Lääne idastumise diskursusest ja vastanduvad niiviisi selgelt kristlikule sümboolikale, sobivad need paremini kokku eesti rahvusromantilise narratiiviga, et meie endi õiget "meie"-identiteeti tuleks otsida kristluse-eelsest paganlusest, enne ristirüütlite "tule ja mõõgaga" sundkonversiooni. Ühtlasi balansseeritakse tundlikult purunenud transtsendentsuse kildude tagaotsimise üldise huvi ja nõukogude aja ateismi kultuuritaustast pärinemisega kaasneva usklikkuse stigma hirmu piiril, püüdes ka võõraste religioonide sümboolikat esitada maksimaalselt kaine, materialistliku ja teispoolsust eitavana.

Hiina taoismi musta ja valgega ümmargust taiji sümbolit, mis kujutab yinyang, nais- ja meesenergia, maa ja taeva, pimeduse ja valguse üha uuenevat tasakaalu, kasutas üks intervjueeritu oma firma logol, põhjendades seda niiviisi:

See taiji märk tulenes ilmselt sellest kooli esialgsest seotusest esoteerikaga. Ja kuna ta tähendab seda... noh, paremini ei oska seda elufilosoofiat 
välja tuua - et alati on valges midagi musta ja mustas on midagi valget, puhtaid värve pole olemas... On ju? Et muhk on tagurpidi lohk ja... alati nad lähevad, alati kõik on liikumises. Kõik, mida võtad, kõik õnnestub sellega ära seletada - et selles mõttes see märk mulle tookord sümpatiseeris. (m 1954, ERA DH 288)

Uuringule EUU 2010 järgnenud konverentsil leiti, et eriti kiiresti on Eesti usklikkus kahanenud aastatel 2005-2010 (Liiman \& Tuisk 2012) ning põhjuste selgitamiseks oleks vaja teha kvalitatiivseid lisauuringuid. 34 elulugu on vähe suurte järelduste tegemiseks, kuid et täiendmeditsiin on Szerszynski järgi üks hulkuva religiooni jaoks välja pakutud valdkondi ja inimkeha võib näha pühadustunde objektina, kuulub minu töö nende vajalike kvalitatiivsete lisauuringute hulka. Paul Heelas leiab Eesti statistiliste andmete erakordsust tõlgendades, et terve religioonisotsioloogia distsipliin peab lähitulevikus seisma suurte muutuste ees ja Eesti annab suure empiirilise panuse arutelusse, mida ja miks tajuvad inimesed elus väärtuslikuna (Heelas 2013: 178).

\section{Kokkuvõtteks}

Võib öelda, et pärast nõukogude bloki raudse eesriide tagant välja murdmist oleme me 21. sajandiks edukalt mitte ainult ühinenud Euroopa ja Põhja-Atlandi liitsüsteemidega, vaid samavõrra innukalt läinud ka üleilmastumise radadele ning hakanud "koguma eksootilisi aistinguid" (Baumani sõnadega väljendudes). Me läänestusime idastunud Läände; suvitama ja kutseoskusi täiendama sõidame läänestunud Itta. Me toome nii Ida kui ka Lääne endale koju kaasa. Kahtlemata teeb selline mitmepalgelisus meid rikkamaks. Et iga asja eest tuleb maksta, võib praeguse pluralismi hinnaks olla näiteks segadus, kes meie, eestlased, siis tegelikult oleme - samas võib selline küsimus mitmekesisuses osalejate eneste silmis olla vaid irrelevantne probleemitsemine.

Eestlaste umbusklikkusele näib mingi vastus paistvat lihtsast tõigast, et NSV Liidu ajal treenis ideoloogiline ajupesu meid pidama isemõtlemist ja vastukultuurilisust enese alalhoiuinstinkti tugisambaks. Küllap ilmneb just see 21. sajandil suures statistilises toetuses heterodokssele ja deviantsele kultusmiljööle nii rahvaloendaja ees kui ka suures joogalembuses. Szerszynski idee "hulkuva religiooni" asupaigast spordis, hariduses ja meditsiinis võimaldab esitada inimestele uskumise valdkonnast ka selliseid küsimusi, mis saavad ristiusu täiesti kõrvale jätta. Eeldan, et nendes selgitustes, miks inimene ühe või teise valiku oma tervise- ja hingeelu probleemidele abi otsimise olukorras langetas, väljendab "hulkuva religiooni" olemus end ilma et tuleks otsesõnu küsida, kas ta usub Jumalasse, eluenergiasse, jätkuvasse enesearengusse või 
millessegi muusse. Kui paljud kliendid usaldavad riiklikku meditsiinisüsteemi, kui paljud täiendmeditsiini võimalusi, kui paljud riiklikku või alternatiivharidust, kui paljud lausa mitte kedagi, sooviksin kunagi edaspidi uurida põhjaliku kvantitatiivse uuringuga - ning esmalt kvalitatiivsete meetoditega leida sellised ennast kirjeldavad väited, millega meil on senisest lihtsam end samastada.

\section{Tänuavaldused}

Avaldan tänu Aili Aarelaiule, Raili Nuginile ja Aida Hatšaturjanile minu tekstide korduva lugemise ja tagasiside eest ning Marju Kõivupuule, Tiiu Jaagole ja Lea Altnurmele minu töös selliste väärtuste nägemise eest, millest ma ise polnud teadlikki.

\section{Kommentaar}

1 Käsitlesin budismi alglegendi ja budistliku manuaalmeditsiini ajalugu oma magistritöös (Kartau 2011a), sellel põhinevas artiklis ajakirjas Pro Folkloristica (Kartau 2011b), samuti eraldi raamatuna (Kartau 2012).

\section{Allikad}

ERA DH - Eesti Kirjandusmuuseumi Eesti Rahvaluule Arhiivi digitaalsed helifailid järjekorranumbritega $287-311$ ja 398-405.

\section{Kirjandus}

Altnurme, Lea 2006. Kristlusest oma usuni. Uurimus muutustest eestlaste religioossuses 20. sajandi II poolel. Tartu: Tartu Ülikooli Kirjastus.

Altnurme, Lea 2012. Mida võiks kirik teada eestimaalase individuaalsest religioossusest. Jõks, Eerik (toim). Astu alla rahva hulka. Artikleid ja arutlusi Eesti elanikkonna vaimulaadist. Tallinn: Eesti Kirikute Nõukogu, lk 193-212 (http://www.ekn.ee/doc/ ajakirjad/09_Lea_Altnurme._Mida_voiks_kirik_teada_eestimaalase_individuaalsest_ religioossusest.pdf -8 . aprill 2019).

Bauman, Zygmunt 1995. Life in Fragments. Essays in Postmodern Morality. Oxford: Blackwell.

Campbell, Colin 1999. The Easternisation of the West. Wilson, Brian \& Cresswell, Jamie (toim). New Religious Movements: challenge and response. London \& New York: Routledge, lk 35-50. 
Campbell, Colin 2002. The Cult, the Cultic Milieu and Secularization. Kaplan, Jeffrey \& Lööw, Heléne (toim). The Cultic Milieu: Oppositional Subcultures in an Age of Globalization. Oxford: Rowman Altamira, lk 12-25 (http://books.google.com/books?id $=\mathrm{CjIYNrOO} 24 \mathrm{IC} \& \mathrm{lpg}=\mathrm{PP} 1 \& \mathrm{dq}=\mathrm{The} \% 20$ cultic $\% 20$ milieu $\& \mathrm{pg}=\mathrm{PA} 14 \# \mathrm{v}=$ onepage $\& \mathrm{q} \& \mathrm{f}$ $=$ false -29 . oktoober 2018).

EUU 2010 = Usust meie elus. Kiriku ja religiooni uuring. Tallinn: Saar Poll (http://www. saarpoll.ee/UserFiles/File/Kiriku_uuring_SLAIDID(1).pdf - 2. aprill 2019).

EUU 2015 = Maasoo, Kai 2015. Elust, usust ja usuelust 2015. Tallinn: Saar Poll (http:// www.saarpoll.ee/UserFiles/File/Elus,\%20usust\%20ja\%20usuelust_2015_ESITLUS_ FINAL.pdf - 26. oktoober 2018).

Geertz, Clifford 1990. Religioon kui kultuurisüsteem. Akadeemia 11, lk 2301-2339.

Hanegraaf, Wouter J. 2005. Forbidden knowledge: Anti-Esoteric Polemics and Academic Research. Aries 5 (2), lk 225-254 (doi: 10.1163/1570059054761703).

Heelas, Paul 1996. New Age Movement. The Celebration of the Self and the Sacralization of Modernity. Oxford, Cambridge: Blackwell.

Heelas, Paul 2013 Eesti kui katselabor - ideaalne näide vaimsuse ja religiooni suundumuste uurimiseks. Uibu, Marko (toim). Mitut usku Eesti III. Valik usundiloolisi uurimusi: uue vaimsuse eri. Tartu: Tartu Ülikooli Kirjastus, lk 167-187.

Henriksen, Jan-Olav 2017. Religion as Orientation and Transformation. A Maximalist Theory. Religion in Philosophy and Theology. Tübingen: Mohr Siebeck.

Jaspers, Karl 1955. Vom Ursprung und Ziel der Geschichte. Frankfurt am Main: Fischer Bücherei.

Jõks, Eerik (toim) 2016. Kuhu lähed, Maarjamaa? = Quo vadis Terra Mariana? Tallinn: Eesti Kirikute Nõukogu.

Kartau, Age Kristel 2011a. Traditsioonilise tai massaaži nuad bo rarn Eestisse jõudmine elulugude andmetel. Magistritöö. Tallinn: Tallinna Ülikool, Eesti Humanitaarinstituut.

Kartau, Age Kristel 2011b. Doktor Shivago pärand Tallinnas ja Saaremaal. Tupits, Ave \& Labi, Kanni (toim). Kuldkalake. Pro Folkloristica 16. Tartu: Eesti Kirjandusmuuseumi Teaduskirjastus, lk 39-59.

Kartau, Age Kristel 2012. Osa teekonnast nirvaanasse. Pildialbum budistliku kultuuriruumi pühapaikadest Tai massaži õpiku juurde ja päikeseturistile. Tallinn: Shivago OÜ.

Krull, Hasso 2012 Uued vabastusliikumised. Aarelaid-Tart, Aili (koost). Nullindate kultuur I. Teise laine tulemine. Tartu: Tartu Ülikooli Kirjastus, lk 147-174.

Leone, Massimo 2012. Motility, Potentiality, and Infinity - A Semiotic Hypothesis on Nature and Religion. Biosemiotics 5 (3), lk 369-389 (doi: 10.1007/s12304-011-9130-4).

Liiman, Raigo \& Tuisk, Tarmo 2012. Eestimaalaste hoiakute muutused usu- ja moraaliküsimustes 1995-2010. Jõks, Eerik (toim). Astu alla rahva hulka. Artikleid ja arutlusi Eesti elanikkonna vaimulaadist. Tallinn: Eesti Kirikute Nõukogu, lk 113-142 (http://www.ekn.ee/doc/ajakirjad/06_Raigo_Liiman_ja_Tarmo_Tuisk._Eestimaalaste_ hoiakute_muutused_usu-_ja_moraalikusimustes_1990-2010.pdf - 4. aprill 2019). 
Lilleoja, Laur \& Raudsepp, Maaris 2016. Cohort-specific value patterns during the new millenium. Nugin, Raili \& Kannike, Anu \& Raudsepp, Maaris (toim). Generations in Estonia. Contemporary perspectives on turbulent times. Tartu: Tartu University Press, lk 36-69.

Lyra, Ahti \& Altnurme, Lea 2004. Tervendamine kui misjoneeriv klientkultus. Altnurme, Lea (toim). Mitut usku Eesti. Valik usundiloolisi uurimusi II. Tartu: Tartu Ülikooli kirjastus.

de la Loubère, Simon 1691. Description du royaume de Siam. Amsterdam: Chez Abraham Wolfgang (https://books.google.ee/books?id=wbQUAAAAQAAJ\&printsec=frontcover\&h $\mathrm{l}=$ et\&source=gbs_ge_summary_r\&cad=0\#v=onepage\&q\&f=false -30 . oktoober 2018).

Mauss, Marcel 1934. Les techniques du corps, Paris (http://classiques.uqac.ca/ classiques/mauss_marcel/socio_et_anthropo/6_Techniques_corps/techniques_corps. pdf - 30. oktoober 2018).

Otto, Rudolf 2003. The idea of the holy: an inquiry into the non-rational factor in the idea of the divine and its relation to the rational, translated by John W. Harvey London: Oxford University Press.

Otto, Rudolf 2012. Püha. Härle, Wilfried \& Põder, Thomas-Andreas (koost). Uuema evangeelse teoloogia põhitekstid. Tartu: Ilmamaa.

Potrata, Barbara 2004. New Age, Socialism and Other Millenarianisms: Affirming and Struggling with (Post)socialism. Religion, State \& Society 32 (4), lk 365-379 (doi: 10.1080/0963749042000308087).

Remmel, Atko \& Uibu, Marko 2015. Outside Conventional Forms: Religion and NonReligion in Estonia. Religion and Society in Central and Eastern Europe 8, lk 5-20 (doi: 10.20413/rascee.2015.8.1.5-20).

Saard, Riho 2013. Kristluse ajalugu selle algusest tänapäevani. Tallinn: Argo.

Schleiermacher, Friedrich 2012. Kristlik usk [1822]. Härle, Wilfried \& Põder, ThomasAndreas (koost). Uuema evangeelse teoloogia põhiteksid. Tartu: Ilmamaa.

Szerszynski, Bronislaw 2005. Nature, Technology and the Sacred. Religion and Spirituality in the Modern World. Malden (Mass.) \& Oxford (UK) \& Carlton (Victoria): Blackwell.

Söderblom, Nathan 1914. Gudstrons uppkomst. Stockholm: H. Gebers (http://www. worldcat.org/title/gudstrons-uppkomst/oclc/27110183 - 30. oktoober 2018).

Taylor, Charles 2007. A Secular Age. Cambridge, MA: Harvard University Press.

Uibu, Marko 2016. Religiosity as Cultural Toolbox: A Study of Estonian New Spirituality. Doktoritöö. Tartu Ülikool: Tartu Ülikooli Kirjastus (https://www.etis.ee/Portal/ Publications/Display/1867f2ad-6e6a-4eb9-b7af-ff07917da980 - 30. oktoober 2018).

Yelle, Robert A. 2016. Semiotics. Strausberg, Michael \& Engler, Steven (toim). The Oxford Handbook of the Study of Religion. OUP, lk 208-219 (doi: 10.1093/ oxfordhb/9780198729570.001.0001). 


\title{
Summary
}

\section{"I wouldn't go to the doctor anyway!" Emic non- religiosity in the expected new religious movements research field}

\author{
Age Kristel Kartau \\ $\mathrm{PhD}$ student in religious studies, University of Tartu \\ age.kartau@gmail.com
}

Keywords: body techniques, faith, lack of faith, manual medicine, materialism, New Age, sociology of religion

The paper "I wouldn't go to the doctor anyway!" presents a study of alternative medicine practices among Estonians, who are allegedly the least religious people in the world. Only 6 percent of Estonians consider religion important in their lives and only 2 percent attend church weekly; $1 / 3$ profess to never having had the experience of the sacred, and another $1 / 3$ have difficulties expressing when and in connection with what they have felt anything being holy. One of the world's leading researchers of New Age, Paul Heelas, has called Estonia "a golden land" for studying trajectories of changing spirituality: "over and above serving to exemplify the 'shattering' retreat of Christendom ... Estonia calls for the transformation of the study of religion ... to the comparative study of sources of significance: their various promises ... or their failures".

The present study is based on 34 life-story interviews, recorded digitally in the years 2008-2019 and stored in the Estonian Folklore Archives. Although the sociological theories of religion consider alternative medicine as the New Age spirituality by default, the interviewees perceive their activity as non-religious. The label 'New Age' is even regarded with hostility. There are some who identify themselves as Christians, and some who see the profitability of using the Buddhist language or Taoist images, but faith per se in any religious doctrine is hard to find.

Soviet ideological brainwashing during the occupation trained Estonians to hang on to thinking for themselves and antagonism-buttressed self-preservation. In a basic values survey, Estonians put autonomy and self-sufficiency (equals autarchia in church terminology) in a very high position, the third among 21 values. This defiance is visible against the church as well as the New Age ideologies, and the state medical system. This might, thus, explain the great support for heterodoxy and the cultic milieu both in the census statistics of the 21st century and the large numbers of Estonians pursuing yoga. Whoever can afford it prefers finding help in Google search and not showing up in a doctor's office.

Among the interviewees there are some who use in their job such oriental body techniques as yoga, acupuncture, Thai massage, and reiki. One person is a close family member of a long-time legendary folk-healer who used forest herbs and had a reputation as a clairvoyant, but in fact had higher education in biology and chemistry and advised clients skilfully by reading chemical elements in blood tests and applying knowledge about chemical content of the plants in the home forest. One woman whose rheumatoidarthritic daughter was treated with modern medicine without satisfactory results for many years turned to Byzantine blood-letting cupping therapy that has been practiced 
for centuries by Scandinavian folk medicine. After sauna suction cups are placed on the skin to force the superficial capillaries to dilate, and then skin is cut intentionally in order to cleanse the organism of toxic residues. She defines herself as believing "in nothing except in herself" - "no witchcraft whatsoever in these therapies", according to her own words.

As Bronislaw Szerszynski has noticed, feral sacrality of the split transcendental axis - "abroad natural and cultural landscape freely roaming around religious symbols and actions" - is floating in society as a free cultural resource for private use in the creation of identities. At least, something similar can be detected from some life stories in this paper: one interviewee confesses that the job of an oriental body therapist allows to "get ever closer to God, the Creator, Buddha, the Intelligent Energy - whatever it is that has created, and keeps creating the Universe and us".

By the 21st century, after breaking free from the Soviet occupation, Estonia has successfully joined not only the European and North Atlantic alliances, but likewise embraced globalisation and started eagerly to "collect exotic experiences" as a landmark of post-modernist lifestyle, according to Zygmunt Bauman. We became Westernised in an Easternised West; for vacations and career enhancement we go to Westernised East.

Szerszynski's idea of the hiding place for "roaming religion" in sports, education, and medicine allows posing questions to people from the realm of belief, while totally leaving aside Christianity. I am assuming that in those explanations about why people choose one or another solution for their health or psychological problems, the "roaming religion" phenomenon expresses itself without having to ask whether a person believes in God, Intelligent Energy, self-realisation, or whatever. Thorough quantitative research is definitely needed, but first, by qualitative methods, the diverse self-describing statements should be found, by which it would be easier for us to identify ourselves.

Age Kristel Kartau omandas humanitaarteaduste magistrikraadi kultuuriteoorias Eesti Humanitaarinstituudist 2011 ja ajaloos Tartu Ülikoolist 1994. Ta on töötanud varem ajakirjaniku ja tõlgina, viimased 15 aastat massöörina meditsiinisüsteemis Ida-Tallinna Keskhaiglas, Qvalitas Arstikeskuses ja eraklientidega ning on nüüd liikumas psühholoogia, hingehoiu ja kogemusnõustamise valdkonda. Age Kartau on Tartu Ülikooli religiooniuuringute doktorant ning tema peamiseks uurimisteemaks on eestlaste uskumine ja uskmatus nähtuna alternatiivmeditsiini ja psühholoogilise abi kaudu.

Age Kristel Kartau received her MA degree in cultural theory from the School of Humanities at Tallinn University in 2011 and her MA in history from the University of Tartu in 1994. She has previously worked as a journalist and translator, as a massage therapist in the health care system, and is currently moving towards psychology, pastoral care, and peer counselling. Age Kartau is a PhD student at the School of Theology and Religious Studies at the University of Tartu, focusing on religious and non-religious beliefs of Estonians from the perspective of alternative medicine and psychological help.

age.kartau@gmail.com 